\title{
Are those real people? Memory and creative resistance
}

Joseph De Lappe

This is the author 's pre-copyedit version of an article published in the first issue of Digital War. The final authenticated version is available online at DOI: https://doi.org/10.1057/s42984-020-00017-8

De Lappe, J. (2020) 'Are those real people? Memory and creative resistance'. Digital War. 
Are those real people? Memory and Creative Resistance

Joseph DeLappe

Abstract:

In this essay the author will describe a personal narrative history as experimental digital artist and the transformation of his creative practice towards the full embrace of an activist creative stance in responses to militarism, violence and the war or terror. Using an autobiographical structure to trace the lineage of works utilizing digital media and public engagement/interventionist or hacktivist strategies to engage the social and political present.

Gulf War Memories

Wandering the aisles of a Home Depot in San Jose, California on January 17, 1991, the music on the radio wafting from above the towering orange racks of goods was interrupted by a special report that the US had commenced aerial bombings in Kuwait and Iraq. "Operation Desert Storm", the "first" Gulf War had commenced. Pushing our twin daughters, who were then just under a year old, my then wife and I stopped, and listened. Such an odd place to hear about the start of an epic conflict on the other side of the globe. The drumbeat of war, which had been months in the making, soon pervaded our lives with $24 / 7$ television coverage complete with gushing news reports, live footage and smart bomb videos.

l'd grown up in San Francisco, attending Saint Monica's Catholic School in the outer fringes of the city next door to the Presidio Army Base. Our school was full of "army 
brats" whose fathers were generally serving on post or abroad in Southeast Asia. These classmates came and went seemingly as frequently as the fog that routinely descended on our neighborhood. As a child I was fascinated by all things military, World War II in particular, building miniature dioramas, enthralled by war movies and the tales of survival of my Hungarian grandmother who, with my mom and aunt had lived thru the siege of Budapest later escaping to the west as refugees of war. My father and uncles had all served in the military - I'd always dreamed of joining the service when I came of age.

The Vietnam war was quite present in my childhood. In the Boy Scouts on a camping trip, at a campfire gathering, I recall a scout leader, an active duty soldier just returned from Vietnam, recalled the interrogation of NVA prisoners - taken as a group up in a Huey helicopter, they were thrown out of the helicopter one at a time until the last one provided the information his interrogators demanded - he too was then thrown to his death. Another of our leaders, a former Marine, got us high on bomber joints in bright yellow rolling papers the same color as his enormous Ford pick-up truck, blasting The Doors on long trips to Boy Scout camp - but that is another story.

The Vietnam war came to an end in 1975, the televised images of the last evacuation from the rooftop of the American Embassy in Hanoi broadcast to an incredulous nation. I was 12 years old. America had lost a war and after this the thought of further American interventions abroad seemed somehow unimaginable. The Reagan years of course changed all that with a return to unbridled patriotism coupled with the subtle progression 
of small overseas military interventions, Grenada, the proxy wars in El Salvador and Nicaragua, followed by the Bush Sr. years with the invasion of Panama.

It seemed, in 1991, that the Gulf War represented a return to form for the USA. We could win a war abroad! America was back! "Operation Desert Storm" marked a new era of highly controlled yet widely consumed real-time televised reporting war to an overeager American audiences. We experienced this 'reality tv' war, seemingly in real-time, through the mediation of broadcast and cable television news, from CNN to the across the board preempted programing on the major broadcast networks. Our experience of the war was mediated, vicarious, exciting and enhanced by slick, sexy computer graphics and specially composed music.

Later that same year, my family moved from San Jose, California, to Tampa, Florida where I took on a research and teaching post at the University of South Florida. Tampa was the home of the recently retired General "Stormin' Norman" Schwarzkopf, the colorful and valorized leader of the victorious Coalition Forces in "Desert Storm". The local video store, to my surprise, had an extensive "Gulf War" video section dedicated to renting the numerous videos documenting our televised war. These were essentially slickly packaged, hyper-patriotic recaps of the coverage of the conflict, created and distributed by the various cable and broadcast tv networks who had so breathlessly covered the invasion the previous year.

There was something oddly disturbing about living in such close proximity to the retired 
General. As well, I had come across an odd bit of information noting that fast food take out sales had seen a marked increase during the televised coverage of "Desert Storm" as people rushed home from work each day to watch the war on TV. The television coverage of "Desert Storm" by the various networks had been broadcast live, 24/7, and most unusually commercial free - without interruption. (To put this in context in the USA at this time outside of the Public Broadcasting Service, all television networks included extensive advertising in the form of 30 -second to one-minute long commercials). There had been a point where, perhaps several days into the war, the various networks started to re-introduce the commercials as well as their regularly scheduled programming. The disturbing and relentless coverage of bunkers full of civilians obliterated by a smart bombs; the massacre of fleeing Iraqi troops; the "highway of death" were now intermixed and juxtaposed with vacuous entertainment and advertising selling dishwashing soap, fast food and cars.

Figure 1: Gulf War Memories, 1993, Mixed Media

These factors all contributed to the conceptualization and creation of what was my first experimental memorial: Gulf War Memories, 1993. A kinetic/sensory work in mixed media featuring a platen of digital image collages combining frame grabs taken from VHS tapes rented from the aforementioned "Gulf War Videos" section at the local video store, mixed with bits of appropriated TV advertising and game show stills - the images were printed as transparencies backlit by fluorescent lighting. Flanking the images on the sculpture were 16 computer box cooling fans blowing the smell from previously 
eaten pieces of Kentucky Fried Chicken - the bones and bits of rotting flesh angled with the fans to create an olfactory assault directed at the viewer. The work is intended as a visceral, discomforting remedial artifact of the real-time, long distance experience of war. We left Florida after two years in 1993. I had been hired for a new post at the University of Nevada, Reno to head up a new digital media program.

In 2001, I watched the attacks of 9/11 on TV, just like most Americans. Turning on the television just before the second tower was hit by United Airlines Flight 175. Two years later, in 2003 the Lower Manhattan Development Corporation launched what became the largest design competition in history - an open call for proposals to memorialize the New York site of the 9/11 terrorist attacks (http://www.wtcsitememorial.org/, 2004). 5,201 proposals were reviewed for this design competition - as part of the process of sharing the competition entries with the public, the LMDC created a searchable online database of entries - "The World Trade Center Site Memorial Competition Exhibition: Expressions of Tribute from Around the Globe" was launched online in January of 2004, to coincide with the press conference to announce the winner of the competition.

The competition was culminating just under a year into the second US-led invasion of Iraq. "Operation Iraqi Freedom" commenced on March 19th, 2003. While it was wholly appropriate to memorialize the 2,726 victims of the attacks of $9 / 11$, I couldn't help but speculate as to the odd confluence of at once creating a memorial to our own dead while conducting an illegal war against a country that had nothing to do with these terrorist attacks and killing many thousands of innocent Iraqis in the process. The 
administration of George W. Bush stopped at nothing to create a path to war through lies and propaganda which sought to lay the blame for those attacks on Saddam Hussein (Dickenson and Stein 2006). I couldn't help but wonder, what would be the memorial to the American soldiers now dying in this, our latest war based on falsehoods and trumped up patriotism? I couldn't help but further speculate that we would never create such a memorial process for the many thousands of Iraqi civilians who were dying in ever greater numbers.

Figure 2: War Movie, detail, 2003, installation and netart

War Movie

During those first few years after $9 / 11$, the wars in Iraq and Afghanistan were constantly in the news. As with the first Gulf War, both of these conflicts were reported, in real-time via 24/7 newscasts on TV and online, which eventually lessened to reports on significant events as the wars dragged on. It was during this formative stage of the war I conceived a project tentatively entitled "War Movie". In my basement studio I translated my experience of these mediated wars to create a world in miniature - bringing my teenage model building skills to bear, constructing hyper-realistic dioramas of scenes inspired by the photographs and news coverage coming from Iraq and Afghanistan. The walls of my studio were covered with images clipped from newspapers and magazines. My workbench was crammed with plastic models and tiny scale recreations of scenes of destroyed buildings and streets. These were essentially to become tiny film sets of the destruction of war - the dioramas were designed in the round to be made kinetic, 
motorized circular platforms that would slowly rotate in front of strategically placed web cameras. The installation was designed to have four interchangable rotating dioramas, each would become the subject of one of four positionable cameras. The intention was to live-stream the resulting moving images online, to create the illusion that one was driving past endless scenes of warfare and it's destruction. l'd worked with an electronics technician to design a simple switcher device that would randomly, according to varying code, cut between the four cameras for different lengths of time. An internet server would feed the live streaming video online, 24/7. The project combined old school miniature special effects techniques with online video technologies to create a simulated, processed visual recreation of our seemingly "forever wars".

It was while working on this piece that I had reason to call in a cable/internet technician to repair my malfunctioning web connection. The technician arrived at my house, I led him to my basement studio to where the internet hub was housed. He immediately noticed the imagery from the wars covering my walls and the models and electronics in the space. Likely mistaking me for a model building geek totally into modern warfare, he enthusiastically noted that he had been in the Air Force and had served in Afghanistan, and with no less glee told me how one of his jobs at Bagram AFB was to fasten blindfolded Taliban and AI Qaeda suspects into coffin like stretchers for their long flights to Guantanamo Bay, Cuba and how they would piss themselves in fear.

After two years of work, "War Movie" was never completed, the project in it's entirety and the contents of my basement studio in Reno, were destroyed in a catastrophic flood 
on January 1st of 2006 in a "flood of the century", which with global warming were now seeming to happen with some regularity. We were out of town at the time. The only piece of research equipment that was not destroyed in this event was my laptop computer which just happened to be with me while visiting family in San Francisco over the holidays. While this was a horrid experience, losing in the process years of slide documentation, precious artworks and equipment, this destruction had essentially wiped the slate clean, freeing me to move forward and implement concepts that had been percolating in my consciousness since the experience of the World Trade Center Site Memorial Competition some years earlier but had been unable to address being so absorbed was I in completing "War Movie".

dead-in-iraq

On July 4th, 2002, the US Defense Department released the "America's Army" game. A first person shooter game as an online recruiting and marketing tool for the US army. "America's Army" quickly became among the top freely downloadable games in the world with 9 million+ registered users (America's Army 2002). This "game" became a crucial aspect of my creative responses to the attacks of $9 / 11$, the conflagration in Iraq and the World Trade Centre Site Memorial competition.

In 2001, actually just months before the attacks of $9 / 11$, I had created an experimental, interventionist work of online gaming performance logging into the online shooter game "Star Trek Elite Force Voyager" using as my avatar's name "Allen Ginsberg". Rather than actually play this online first person shooter, I would stand in place and utilize the 
in-game text messaging system to perform/recite, word for word, Ginsberg's seminal beat poem "Howl" in it's entirety (delappe.net 2001). This was a type of live, online gaming street theatre - an experiment in networked performativity - considering internet-based gaming shooter maps as a new type of public space. Following this initial experiment, I created a series of online performance works over the next few years: ranging from "Quake/Friends" recreating an entire episode of the TV sitcom, "Friends" inside a Quake server (2003); to reenacting all three of the Presidential debates between George W. Bush and John Kerry, each in a different gaming environment for "The Great Debates" (2004). These were experimental interventions into online games seeking to interrupt and engage in acts of playful mischief.

The America's Army game had been on my radar for some time, this was definitely a serious game and perhaps called for a very specific response. Could a game serve as the location for a memorial? To create a protest? "America's Army", became the territory for exploring such possibilities. I started "dead-in-iraq" three months after the afore-described destruction of my studio, on March 19th, 2006, to coincide with the 3rd anniversary of the start of the Iraq conflict. I created an avatar with the name "dead-in-iraq" and entered the game. I drop my weapon, standing in place and manually type into the game's live text messaging system, "Gutierrez, Jose Antonio, 22, Marine, March 21, 2003", the name, age, service branch and date of death of the first US service member to have been killed in the Iraq war. This was the first name of what was a fleeting, consecutive, digital roll call fed manually into this facile, digital simulation of war. As "dead-in-iraq", I proceeded to type, standing in position and typing until I was 
invariably killed by one of the other players. My texts would appear on the screens of every other player in that particular match. After death, I would hover over my dead avatar's body and continue to type as the simulated online combat proceeded around me. Upon being re-incarnated in the next round, I would continue the cycle. An in-game action as a memorial to those military personnel who were being killed in this misbegotten war. My actions were as well intended as a cautionary, thought-provoking gesture.

Figure 3: dead-in-iraq, 2006-2011, online gaming intervention

This work proved to be highly controversial. The reactions of other players within the gamespace were generally fierce and angry. "This is a game!", "I don't give a fuck!" to the plaintive "Are those real people?" were typical of the text responses received from other players. On many occasions I was booted from a given game server after a unanimous vote by the other players - this I viewed as a victory of sorts - my gesture had indeed interrupted their game play and the other players were paying attention to my messaging. I looked at this as a type of conscientious spamming. It was no surprise that the hyper-patriotic mood of the country, and particularly gamers, were far from welcoming to a work of interventionist protest and memorial taking place in their computer game. As a result of the many online news stories written about this work and the several TV and radio pieces created, I found myself very much under attack and on the defensive regarding my actions. 
The apex of these reactions occurred when I was contacted by the older brother of a soldier who had been killed in Iraq. Lee Hutchinson sent me a respectful, heartfelt email, explaining that while he respected my right to conduct this action, he didn't agree with what I was doing and that his brother, Army Pfc. Ray J. Hutchinson, who was killed by a roadside bomb in Iraq in 2003 (Military Times 2003), had supported the war and believed in his mission. He kindly requested that I not include his brother's name in my action.

In conceiving "dead-in-iraq", my biggest concern was how my actions might negatively impact those family members who had lost loved ones to this conflict. I checked through my progress in going through the growing list of names downloaded from i.casualties.org - I found I had already typed in his brother's name. I replied to him to express my deep condolences over the loss of his brother while at the same time hoping to justify to him the reasons behind my actions. I wanted him to know that regardless of how one viewed the war in Iraq, that I believed his brother died in service to all of us, that as a US tax-payer and voter I was implicated in his death and that my actions were in part a way for me to make a small gesture of remembrance and yes, to call to question the circumstances surrounding the war and the methods being used to recruit young people to go and fight and possibly kill and die. He and I were invited together to be remotely interviewed on National Public Radio (Weekend America 2006). We had a friendly discussion surrounding the circumstances of him contacting me regarding my work and I like to think both benefitted from sharing our viewpoints with each other. 
"dead-in-iraq" for me was a way to close a circle, to call attention to the fact that this "game" was in fact online military territory and was directly connected and implicated, as we all were, in the very real war happening on the other side of the globe. The typing of the names into the text stream of an in-game digital space, where they would appear for a brief moment in the text chat scrolling up the screens of those in that particular match, was the digital equivalent of the chiseling the names of fallen heroes in stone.

A prime motivation for making "dead-in-iraq' was deeply personal. I mentioned earlier that I had always dreamed, as a young man, of joining the army. As a 17 year old in my last year of high school an army recruiter came to my house at my behest - the next step would have been to visit a recruiting office to sign my papers of enlistment. The recruiter was a Vietnam veteran. To my surprise, and my mother's relief, he actually talked me out of signing up - "it is not for everyone...". I don't know why he did this but I am forever thankful - he was one of those people who nudged me away from what would have been a very different life. I looked at my actions in the "America's Army" game as being a way to pay this forward - if my actions had the effect of encouraging even a few young men or women away from thinking about signing up for the army then the project was, as far as I am concerned, wholly worthwhile.

"dead-in-iraq" ended on December 18th 2011, the official withdrawal date of the last U.S. troops in Iraq, on this day, I completed the final input of the remaining names from a total of 4484 of all the soldiers killed in the conflict. 
"We don't do body counts"...quote (REF 10)

Iraqimemorial.org

An accurate accounting of the civilian dead from the Iraq conflict has never been

created. Estimates of civilian deaths resulting from "Operation Iraqi Freedom" and the resulting insurgency run from 200,000 to over 2 million deaths (Wikipedia 2020). The issue of civilian casualties in the war in Iraq was and remains a contentious subject. During the war the balance of media reporting on the conflict, while obsessed with US military casualties, often gave little mention to the many thousands of civilians suffering and dying in the war. In light of these facts and that my country would never undertake to create an official memorial process to recognize the deaths of civilians in this conflict, I chose to respond. iraqimemorial.org was created as an online call for artists, designers, architects or any other interested creative individuals or collaborators to share concepts for proposed, imagined memorials dedicated to the many thousands of Iraqi civilians being killed in the War in Iraq. Launched in 2007, over a two year period, 180 proposals and projects were uploaded by participants to be featured on the website.

Figure 4: iraqimemorial.org, 2007, crowdsourced website repository and exhibition A jury worked to select the top entries to the project - there was no "winner" of the competition but a gathering of selected works were adapted to create a traveling exhibition that was shown at several locations in the USA, perhaps most significantly 
opening at The Elizabeth Foundation for the Arts, NYC on September 9th, 2011, just two days before the official WTC memorial site was open and dedicated on the tenth anniversary of the 9/11 attacks. iraqimemorial.org was an activist gesture of DIY online crowdsourcing - a call to action for the creative community to help recognize and provide a context to develop contemporaneous memorials to the victims of a war in progress. This project as well connected me directly with an array of international creatives opposed to the war and it's consequences, including Iraqi expatriates; former members of the military who had served in the war, now actively opposing such; and artists and architects many of whom have since become friends, collaborators and allies. The project currently exists online as an archive of proposals and projects (iraqimemorial.org 2007)

Both of these works are interventionist and political through a creative and conceptual exploitation of the Internet. On the one hand exploiting and questioning the context and gameplay of a U.S. government funded propaganda and recruiting game - on the other, utilizing the possibilities of the Internet for an open international project that invites participation of an international community to contribute to and establish a cross-cultural context for the memorialization and questioning of civilian casualties in modern warfare.

"dead-in-iraq" and "iraqimemorial" could be considered as co-equal projects, developed consecutively, they represent significant steps in my evolution and growth as an artist and activist. These works have been deeply transformative on a personal level and represent the ultimate, full-on embrace of the politicization of my practice as an artist. I 
engaged these works, "dead-in-iraq" and "iraqimemorial.org" with a sense of clarity of purpose and meaning that I had never experienced in my previous work as an artist. It was thru these works that I came to be the artist that I was meant to be.

Killbox

The official end of the Iraq war in 2011 occurred during a time frame when America was embracing a new weapon to remotely kill its enemies in the never ending "war on terror". I'd become interested in America's newfound reliance on weaponized UAV's (unmanned aerial vehicles) that had become so essential to the Obama administration's effort to eliminate terrorists abroad. In seeking to avoid the messiness of the Bush era's "extraordinary rendition" program and the use of dark sites and the prison at Guantanamo Bay, Cuba to detain and torture detainees - it was seemingly preferable to utilize these new remote weapons in a program of targeted assassinations of America's enemies.

Commencing in 2004, Western military and intelligence services have enthusiastically embraced the use of armed, unmanned aerial vehicles (UAV) as weapons of choice against AI Qaeda and ISIS in conflict zones which include: Iraq, Afghanistan, Yemen, Somalia, Libya and Pakistan. The Bureau of Investigative Journalism estimates that in the North Waziristan region of Pakistan alone, between 2004 and 2015, under the Bush and Obama administrations, 430 minimum confirmed strikes have killed an estimated 4026 people; of these, it is estimated that approximately 960 civilians have been killed, including 207 children. (Bureau of Investigative Journalism 2020) 
Drone warfare brings together gamification, remote communications/satellite and internet technologies and most significantly, the ability to see war in real-time via media technologies has been morphed to become intrinsic to the actual process of killing. Drone pilots housed in command and control trailers on military bases from Las Vegas to New York State, fly hundreds of sorties daily, surveilling and targeting enemies from a distance. As with the civilian casualties from the Iraq conflict, the number of innocents killed in the hundreds of drone strikes conducted since 2006 has been seriously underreported by the Bush, Obama and Trump administrations alike (Fabian 2019).

As with the invasion of Iraq, the underreporting of civilian casualties of Obama's drone wars became a bit of an obsession for me. A series of works seeking to call attention to our drone wars were created, these included: "The Cowardly Drones" (2013); "The Drone Project: A Participatory Memorial"(2014); "In Drones We Trust" (2015), among others.

In 2015 I was approached by Turbulence.org to submit a proposal for a commissioned new work - as I had been working for so long to intervene and engage computer games in my creative practice it seemed logical to suggest that it was time I actually worked to create a video. The game would be about drone warfare. I travelled to Dundee, Scotland, to work with a team of collaborators. We set out with the goal to create a serious game that would at once engage audiences in an experience of play while utilizing gaming technology to create a meaningful and empathic experience. How might 
we use gaming to create a simulated experience of what it might be like to be a drone pilot on the one hand, or a civilian on the ground? The resulting project was entitled "Killbox". We created an interactive installation and downloadable computer game that critically explores the nature of drone warfare, its complexities and consequences. It is an experience that explores the use of technology to transform and extend political and military power, and the abstraction of killing through virtualisation. "Killbox", was designed to involve players/participants in a fictionalized interactive experience in a virtual environment based on a documented drone strike in Northern Waziristan, Pakistan (Democracy Now 2013).

Figure 5: Killbox, 2016, video game

In the game, players are given the choice between what are two interconnected perspectives - either to play as a child in a Waziri village in Pakistan living under the audible threat of a drone circling unseen above - or as that of a remotely based drone pilot targeting the same location from afar.

As the drone pilot, the players role is to acquire and destroy a target in a controlled, linear and realistic simulated experience - disconnected from the act by thousands of virtual miles. Slowly circling the target area from above, the pilot is both hugely powerful and yet severely limited in what they can actually do. The drone pilot's sense of the experience space is confined and defined by the lens of the technology and dialogue with unseen others (the sensor operator and command control/CIA). From their 
high-altitude vantage point, the player is protected and disassociated from the target area.

The second player is a villager. This is an abstracted vision of village life as experienced through the eyes of a child. Their movements through a stylized simulated landscape involve exploring the environment and interacting with other villagers. In this perspective, the player is free to do what they like, to explore and to interact however they choose in an open and free environment without defined goals. Interactions are simple and delightful, with the aim to engage the player's senses in a responsive, playful and immersive world.

The player and other characters in this perspective are represented by animated dots. We discovered in our research several maps of drone strikes marking civilian victims as red dots (Rogers 2012). These dots are representative of the "data points" used by information visualisations on drone strikes. We aim to reverse this by giving these statistical representations life through movement and a sense of context - humanizing statistical markers by literally bringing such dots to life. Further, the use of these dots define the abstracted and reduced aesthetic of this part of the experience. This helps to free the audience from any visually preconceived notions and allow for an experience defined through playful participation.

As the two players are absorbed in their particular world views, there will be an inevitable moment when the experience of the villager and pilot collide. The pilot 
launches a missile. The child on the ground is either killed outright, or seriously wounded only to die in a second "double tap" missile launch. It is at the point of impact that the interrelationship of the players becomes clear, and both are provided space for reflection - to question their actions and the experience itself. When the smoke clears, the game ends, at this point the game reboots, the roles are reversed - the pilot becomes the civilian child on the ground, the child becomes the drone pilot.

"Killbox" was designed to be ideally experienced as a two-person game at a specially designed kiosk, or at two computers facing off across a table. Two players face each other across their screens. This guarantees a moment of cognition when the inevitable break from the immersive experience, post drone strike, creates an awkward moment of considering what has been done by or to the other player. Immersive play becomes a platform to examine empathy, complicity, control and death.

Looking back on America - Elegy: GTA USA Gun Homicides A back tracking camera, as if revealing the end of a film, retreats down a typical American street. Pedestrians wander, seemingly aimless, the scene is interrupted by the sound of gunfire, people scatter, some raise weapons and shoot, nearly everyone is killed. At the bottom of the screen is a date, $07 / 10 / 18$, below which is a number. As the people are shot dead, the number keeps a grim tally. "God Bless America" plays in the back ground, mixing with the sound of gunfire and the screams of victims. The song ends, the process repeats, the death count rises. This is the on screen action that takes place in a project designed to utilize an off the shelf computer game that has been 
modified to function as a data visualization of actual gun homicide totals in the United States.

On February 14th, 2018, a lone gunman armed with a military style AR15 semiautomatic rifle killed 17 students at the Marjory Stoneman Douglas High School in Parkland, Florida. The year prior to this I had left the United States to live and work abroad in Scotland, taking on a research professorship at Abertay University in Dundee. As one of a handful of Yanks working in the division of Games and Arts, I'm often the one contacted by local and national press for interviews regarding various issues surrounding games and violence.

Just after the grisly killings in Florida, President Trump made comments to the effect of blaming videogames for such violent mass shootings (Kain 2018). Soon thereafter I was contacted by a local newspaper, The Courier, to provide some commentary. Prior to the interview I did some background research. I had just the month prior built on location in Los Angeles for an exhibition a work called "Thoughts and Prayers" in reaction to America's mass shootings, in the form of a 14 foot long low polygon sculpture of an AR15 assault rifle (2018). I came to find some rather startling statistics. In 2017 there had been 15,686 deaths due to gun homicide in the USA (if one were to include suicides using guns this number would be nearly tripled). In comparison, as of the writing of this essay, the USA counted 8464 military deaths as combined from the wars in Iraq and Afghanistan (icasualties.org 2020). America would seem to be at war with itself. The connection between actual real world violence and video game violence has 
been carefully researched with very little evidence that the latter leads to the former. In fact one study shows quite the opposite with the release of major gaming titles actually coinciding with the slight dip in youth crime rates. (Carey 2013). I discussed these findings and shared my opinion that Trump and others were simply looking to create a distraction to the very real issue of the easy access to guns in the United States.

In part a reaction to this experience and as a way to continue to creatively explore the complexities of real world gun homicides and gaming violence, I conceptualized a project to utilize a popular shooter game as a data visualization system. This took the form of what became the afore described "Elegy: GTA USA Gun Homicides" transforming the popular open world shooter "Grand Theft Auto 5"(Rockstart Games 2013) into a self-playing, 24/7 visualization of actual gun homicide data - a daily reenactment of the total number of USA gun homicides since January 1st, 2018.

Figure 6: Elegy: GTA USA Gun Homicides, 2018-2019, live streamed gaming modification/data visualizer

"Elegy" was launched on America's independence day holiday, July 4th, 2018, by this date, there had been 7,293 gun homicides in the United States. This data was fed directly into a modified version of GTA 5 , starting at "0" that midnight central time the game plays thru an accelerated reenactment of all the gun homicides since January 1 st over the course of the day, ending at midnight. Automated "bots" or in game lingo "NPC's - non playing characters" enact the continuous mayhem. Each day at 12:01am 
central time, the body counter resets itself to zero, the previous days total of gun homicides are added to the overall count and these are in total reenacted over the next 24 hour period, and so on.

The project works from a daily update of total 2018 gun homicides as scraped from the Gun Violence Archive online (gunviolencearchive.org 2018). Gun homicide totals in the USA since January 1st are revised on this website each day as they are reported. "Elegy" uses this live data to feed the action within the modified game - essentially playing these gun death stats in an endless, growing loop.

Elegy reenacts these deaths as seen from the slow backward tracking shot meandering through the gamespace to record the action in real-time. The work is accompanied by a looping soundtrack, of the first radio recording of "God Bless America" as sung by Kate Smith in 1938. The project was live streamed $24 / 7$ on Twitch.tv, the online source for the sharing of live videogame play. Over the one-year operation of the piece online "Elegy" garnered over 235,000 views. The "Elegy" mod ran for one year from July 4th, 2018 to July 4th 2019. Over the two year period during which Elegy operated live and online, there were, 14,718 and 15,336 gun homicides, respectively in 2018 and 2019.

\section{Conclusion}

In writing this essay, I recognize a crucial junctures where things have shifted significantly in my creative practice. The invasion of Iraq in 2003 for certain, the WTC site memorial process but perhaps, just as significantly, the flood and destruction of my 
studio in 2005. Prior to this catastrophic event, much of my work combined aspects of the digital with the analogue physical, small and large scale physical sculptures and electromechanical installations. The online gaming performance works, which started in 2001 with Howl, were part of a larger practice to conceptually and critically engage new media technologies, yet these were not the primary focus of my work. It was the confluence of the flood and that taking on of "dead-in-iraq" that immediately followed that firmly shifted my work into deeper digital territories, ie: iraqimemorial.org, Killbox, The Cowardly Drones, etc. I've certainly not forgone physical production but this has significantly shifted in recent years to embrace the temporal: these include the mixed-reality performance work such as "Gandhi's March to Dandi in Second Life" (2008); to the resulting monumental scale cardboard reproductions of my Gandhi avatar (2008); the online performance "Chatroulette: Discipline and Punish" (2011); and "Jasmine: A Drone Memorial" (2018) to name a few. The material aspect of my practice has indeed become much more ephemeral since the destruction of my studio space. There is some kind of odd symmetry here with the emergence of remote drone warfare and the ephemeral nature of my work. We certainly react to our world as much as we try to create such.

As with my earlier project, "dead-in-iraq", "Elegy" functions to engage players as witnesses to reimagined, simulated real world violence and death as recreated in a simulative game space. By repurposing video game spaces, imaginary killing fields of play are reified to interrupt, engage and bear witness. In gaming theory "the magic circle" is a space where the rules of the real world are superseded and replaced by the 
created reality of the game space (Huizinga 1938). The magic circle functions to create a virtualized or imagined space for fantasy and the artificial to become, temporarily, the real. It is a bit like the suspension of disbelief but in a ludic situation of play. In these works it is my goal not to pierce the "magic circle" but to work within the confines and codified realities of game space to perhaps enhance the end user experience with additional content and meanings. To expand the possible impact of such gaming contexts thru shattering certain conventions but in a way that can at once be critical yet engaging. In much of my work, from "dead-in-iraq" to "Killbox" to "Elegy", the calculus whereby in game violence leads to real world violence is turned on it's head - seemingly ungraspable death and violence from reality temporarily invades these ludic arenas of carnage with the real. In the words of author Patrick Crogan in writing about dead-in-Iraq, he notes "DeLappe's work is a decisive familiarizing gesture." (Crogan $2011,113)$

In my work, the intent is to forge connections between concept, object, interaction and a questioning/critical stance regarding issues ranging from militarism and violence to contemporary geopolitics. The philosophical basis for my work lies in the belief that it is essential, as an artist and citizen of the world, to engage in and challenge the norms and expectations of the digital present and the larger cultural context. Past projects and ongoing efforts share an approach to critical and conceptual positioning as an artist - developing works that inquisitively engage issues of militarism, memory, politics, history, physicality and the virtual. Throughout the work I seek to find a synthesis between conflicting processes and ideas: analog/digital, concept/happenstance, 
physical/virtual, politics/art - all with a dedicated consideration and questioning of contemporary technologies and artistic practice.

Previously I mentioned the "magic circle" in relation to games. I would go further here to propose that the "magic circle" could serve as an apt metaphorical construct for the belief system in place in the United States. This is an insular circle of belief held as an article of faith by most Americans of the superiority of our country, the benevolence and inherent righteousness of US power as expressed throughout the world. In this sense I would suggest that what I am hoping to accomplish with all my work is to create projects that challenge and interrupt such circles of belief. Through the afore described projects, I have sought to forge connections, explore the thoughtful processing of information, and develop exigencies that inform, challenge, provoke and question.

\section{List of References}

America's Army. 2002. America's Army. https://www.americasarmy.com/

Antelava, Natalia. 2009. Who is counting the bodies in Iraq? BBC News at One. 11 December. http://news.bbc.co.uk/1/hi/world/middle_east/8405894.stm

Bureau of Investigative Journalism. 2020. Strikes in Pakistan.

https://www.thebureauinvestigates.com/projects/drone-war/charts?show_casualties=1\&show_in juries=1\&show_strikes=1\&location=pakistan\&from=2004-1-1\&to=now

Carey, Benedict. 2013. Shooting in the Dark. The New York Times. 11 February.

https://www.nytimes.com/2013/02/12/science/studying-the-effects-of-playing-violent-video-game s.html?ref=science \&_r=1\&

Crogan, Patrick. 2011. Gameplay Mode: War, Simulation and Technoculture. University of Minnesota Press. 113

DeLappe, Joseph. 2007. iraqimemorial.org.

http://www.iraqimemorial.org

DeLappe, Joseph. 2020. Joseph DeLappe Artist's Website.

http://www.delappe.net

Democracy Now. 2013. "Too Scared to Go Outside": Family of Pakistani Grandmother Killed in U.S. Drone Strike Speaks Out. 31 October. 
https://www.democracynow.org/2013/10/31/too_scared_to_go_outside_family

Dickinson, Tim and Stein, Jonathan. 2006. Lie by Lie: A Timeline of How We Got Into Iraq.

Mother Jones. September/October 2006.

https://www.motherjones.com/politics/2011/12/leadup-iraq-war-timeline/

Fabian, Jordan. 2019. Trump nixes public report on drone-strike deaths. The Hill. 6 March.

https://thehill.com/homenews/administration/432871-trump-nixes-public-report-on-drone-strike-d eaths

Gun Violence Archive. 2018. Gun Violence Archive.

https://www.gunviolencearchive.org/

Huizinga, Johan. 2016. Homo Ludens. Ranchos de Taos: Angelico Press

icasualties.org. 2020. Iraq Coalition Casualty Count.

http://icasualties.org/

Kain, Erik. 2018. Trump Blames Violent Video Games For School Shootings -- Here's Why He's Wrong. Forbes. 22 February.

https://www.forbes.com/sites/erikkain/2018/02/22/trump-blames-violent-video-games-for-schoolshootings-heres-why-hes-wrong/

Military Times. 2003. Honor the Fallen.

https://thefallen.militarytimes.com/army-pfc-ray-j-hutchinson/256950

Rockstar Games. 2013. Grand Theft Auto V.

https://www.rockstargames.com/V/

Rogers, Simon. 2012. US drone strikes listed and detailed in Pakistan, Somalia and Yemen. The Guardian. 2 August.

https://www.theguardian.com/news/datablog/2012/aug/02/us-drone-strikes-data

Weekend America. 2006. War Games. National Public Radio, 28 October .

http://weekendamerica.publicradio.org/programs/2006/10/28/war_games.html

Wikipedia. 2020. Casualties of the Iraq War.

https://en.wikipedia.org/wiki/Casualties_of_the_Iraq_War

WTC Site Memorial. 2004. World Trade Center Site Memorial Competition.

http://www.wtcsitememorial.org/. 
Figure 1

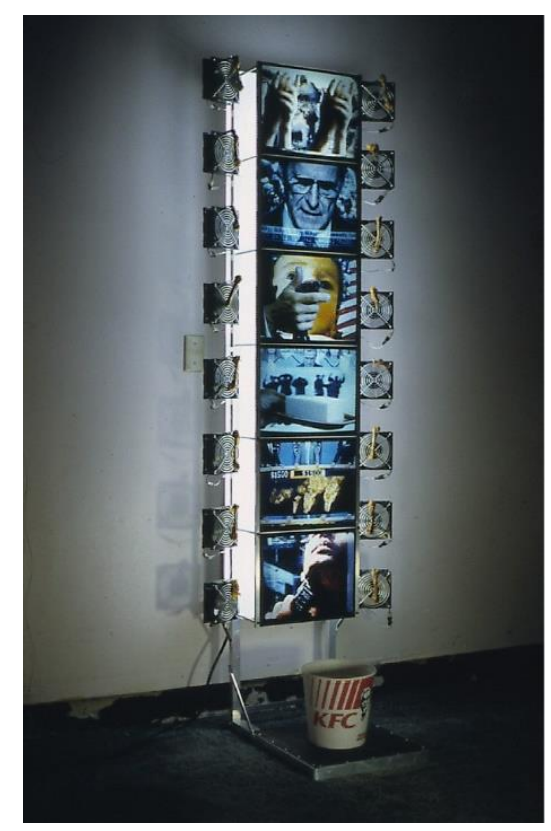

Figure 2

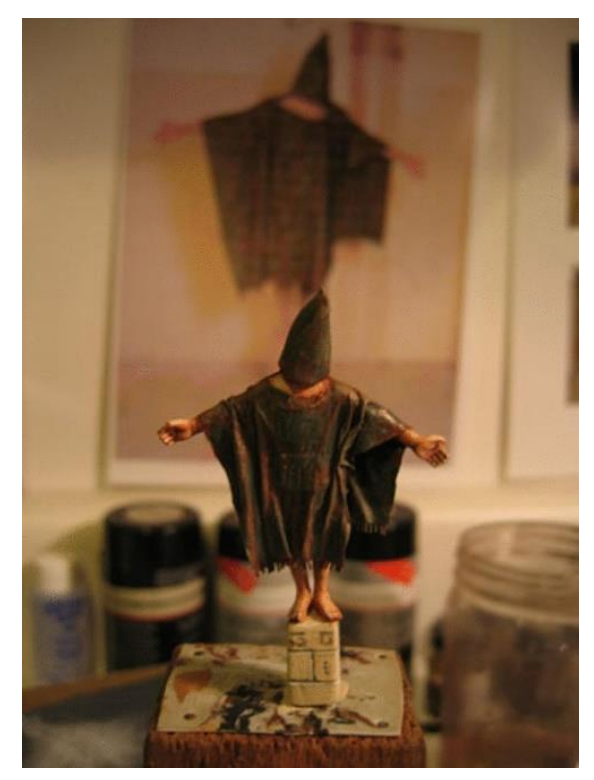

Figure3

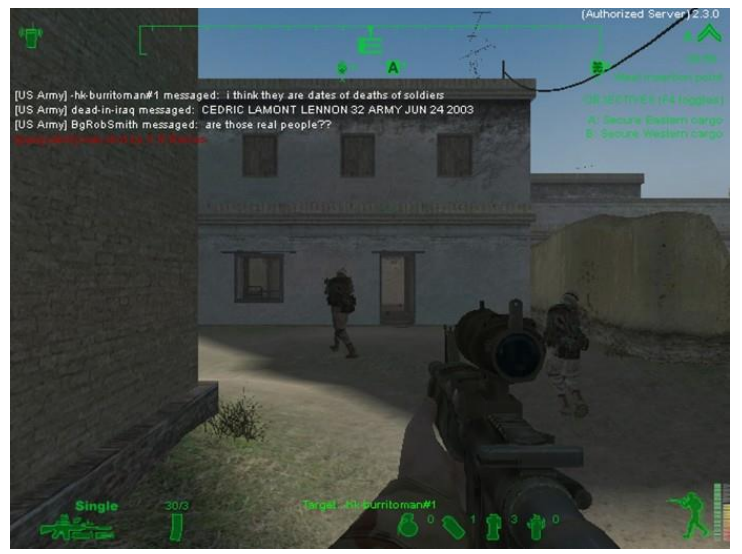


Figure 4

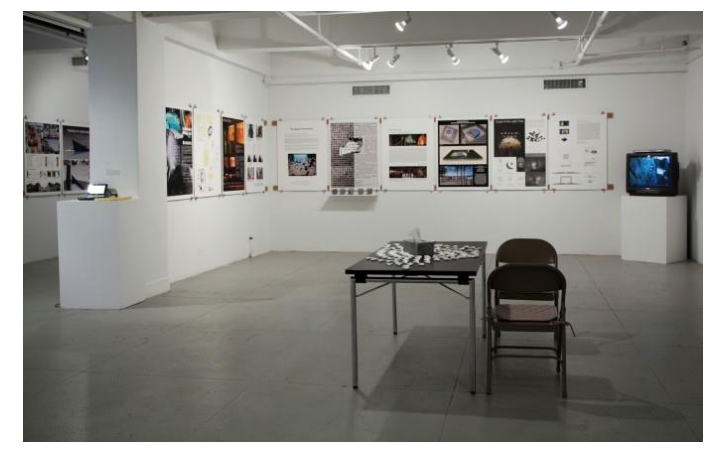

Figure 5

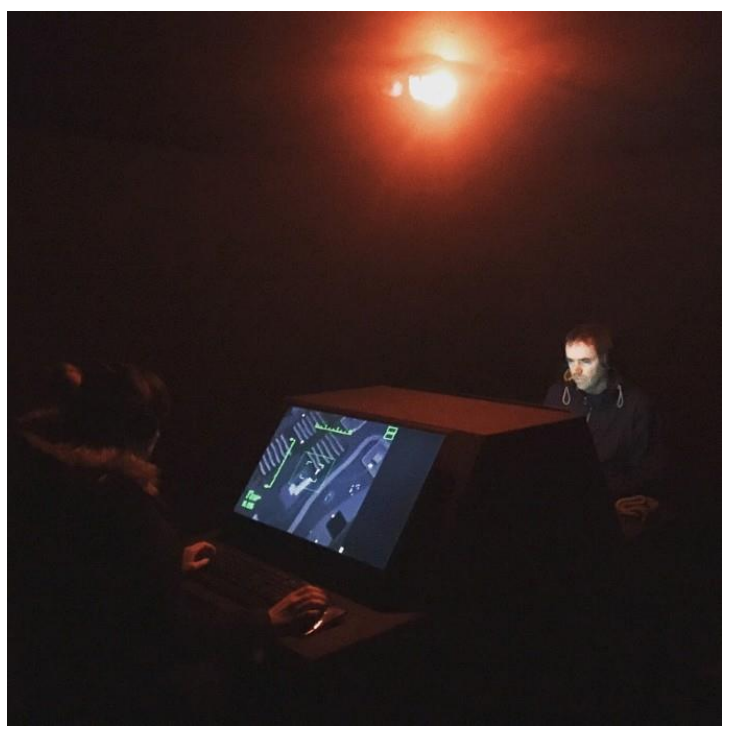

Figure 6

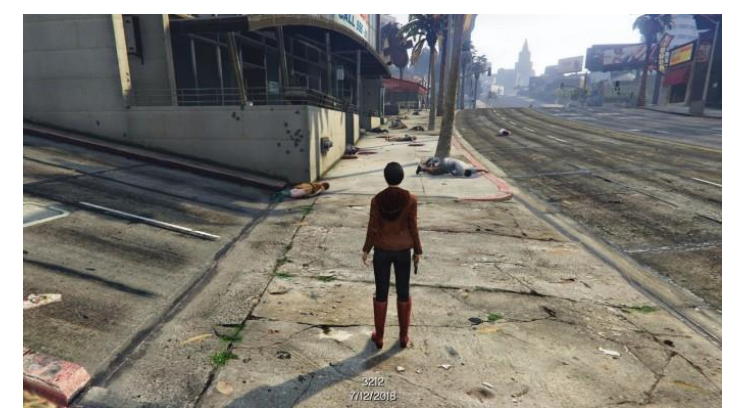

